Volume 14 (2) (2018): $87-100$
Jurnal Borneo Administrator
$\mathrm{p}$-issn : 1858-0300; e-issn : $2407-6767$
$\mathrm{http}: / /$ samarinda.lan.go.id/jba
$\mathrm{DOl}: 10.24258 / \mathrm{jba} . \mathrm{j} 14 \mathrm{i} 2.326$

\title{
ANALISIS TRANSFORMASI EKONOMI DI PROVINSI KALIMANTAN TIMUR
}

\section{ANALYSIS OF ECONOMIC TRANSFORMATION IN EAST KALIMANTAN PROVINCE}

\author{
Zhikry Fitrian \\ Badan Penelitian dan Pengembangan Daerah (Balitbangda) \\ Provinsi Kalimantan Timur \\ JI. MT. Haryono No. 126 Samarinda \\ email : zicree@gmail.com
}

Naskah diterima: 6 Maret 2018; revisi terakhir: 17 April 2018; disetujui: 20 April 2018

\begin{abstract}
East Kalimantan Provincial Regulation Number 7 Year 2014 concerning East Kalimantan Provincial Regional Plan (RPJMD) of 2013-2018 stipulates that the acceleration of economic transformastion is one of the East Kalimantan Province's medium-term development strategies. The economic transformation is done to reduce the economic dependence of East Kalimantan Province on mining and quarrying sector by developing manufacturing sector of leading commodities. This study aims to find out whether the economic transformation in East Kalimantan Province has been implemented as proclaimed by East Kalimantan Provincial Government. Data analysis was conducted by calculating location quotient (LQ) index to find out which sectors are the economic base in East Kalimantan Province as well as shift-share analysis to identify whether economy structure transformation in East Kalimantan.

$L Q$ index calculation shows that mining and quarrying sector is the only base economic sector in East Kalimantan Province, while manufacturing sector has not become the economic base sector in East Kalimantan Province throughout 2010-2016. Meanwhile, result of the shift-share analysis shows that mining and quarrying sector remain the sector that sustains East Kalimantan Province economy throughout 2010-2016. Meanwhile the manufacturing sector still has slow economic growth and low competitiveness. This indicates that the economic transformation in East Kalimantan is still not running as proclaimed by the East Kalimantan Provincial Government.
\end{abstract}

Keywords: economic transformation, manufacturing, mining and quarrying, location quotient, shift share. 


\begin{abstract}
Abstrak
Peraturan Daerah Provinsi Kalimantan Timur Nomor 7 Tahun 2014 tentang Rencana Pembangunan Jangka Menengah Daerah (RPJMD) Provinsi Kalimantan Timur Tahun 2013-2018 menetapkan bahwa percepatan transformasi ekonomi merupakan salah satu strategi pembangunan jangka menengah Pemerintah Provinsi Kalimantan Timur. Transformasi ekonomi tersebut dilakukan untuk mengurangi ketergantungan perekonomian Provinsi Kalimantan Timur terhadap sektor pertambangan dan penggalian dengan cara meningkatkan sektor industri pengolahan komoditas unggulan. Kajian ini bertujuan untuk mengetahui apakah transformasi ekonomi di Provinsi Kalimantan Timur telah berjalansebagaimana dicanangkan oleh Pemerintah Provinsi Kalimantan Timur. Analisis data dilakukan dengan menghitung indeks location quotient (LQ) untuk mengetahuisektor yang menjadi basis ekonomi di Provinsi Kalimantan Timur serta analisis shift share untuk mengetahuiperubahan struktur ekonomi Provinsi Kalimantan Timur. Perhitungan indeks LQ menunjukkan sektor pertambangan dan penggalian merupakan satu-satunya sektor basis di Provinsi Kalimantan Timur. Sedangkan sektor industri pengolahan belum menjadi sektor basis di Provinsi Kalimantan Timur pada periode 20102016. Sementara itu, hasil analisis shift share menunjukkan sektor pertambangan dan penggalian merupakan sektor yang menopang perekonomian di Provinsi Kalimantan Timur sepanjang tahun 2010-2016. Sedangkan sektor industri pengolahan masih memiliki pertumbuhan ekonomi yang lamban dan berdaya saing rendah. Hal tersebut mengindikasikan bahwa transformasi ekonomi masih belum berjalan sesuai dengan yang dicanangkan oleh Pemerintah Provinsi Kalimantan Timur.
\end{abstract}

Kata kunci: transformasi ekonomi, industri pengolahan, pertambangan dan penggalian, location quotient, shift share.

\title{
A. PENDAHULUAN
}

Dominannya sektor pertambangan dan penggalian yang bergantung pada Sumber Daya Alam (SDA) yang tidak terbarukan pada perekonomian Kalimantan Timur tentu tidak akan dapat berlangsung selamanya. Diperlukan perubahan paradigma bagi perekonomian di Kalimantan Timur untuk tidak lagi bergantung pada sektor pertambangan dan penggalian tersebut. Pemerintah Provinsi Kalimantan Timur tentunya menyadari dan terus berupaya untuk melakukan upaya-upaya. Salah satu upaya yang dilakukan berupa pencanangan program transformasi ekonomi secara bertahap dengan meningkatkan nilai tambah dan produktifitas pada SDA yang terbarukan.

Dalam Peraturan Daerah Provinsi Kalimantan Timur Nomor 7 Tahun 2014 tentang Rencana Pembangunan Jangka Menengah Daerah (RPJMD) Provinsi Kalimantan Timur Tahun 2013-2018, ditetapkan bahwa salah satu strategi pembangunan jangka menengah Provinsi Kalimantan Timur adalah melakukan percepatan transformasi ekonomi. Dalam RPJMD tersebut juga disebutkan bahwa pembangunan ekonomi wilayah Provinsi Kalimantan Timur ke depan adalah membangun keterkaitan hulu dan hilir (industrialisasi) dari komoditas-komoditas unggulan yang dapat menjadi basis perekonomian Provinsi Kalimantan Timur masa mendatang (Fitrian, 2017).

Strategi percepatan transformasi ekonomi tersebut sebenarnya sudah sejalan dengan arah kebijakan umum pembangunan nasional 2015-2019 yang tertuang di dalam Rencana Pembangunan Jangka Menengah Nasional (RPJMN) 2015-2019. Arah kebijakan umum pembangunan nasional 2015-2019 yang pertama adalah meningkatkan pertumbuhan ekonomi yang inklusif dan 
berkelanjutan. Pertumbuhan ekonomi yang berkelanjutan tersebut ditandai dengan terjadinya transformasi ekonomi melalui penguatan pertanian, perikanan dan pertambangan, berkembangnya industri manufaktur di berbagai wilayah, modernisasi sektor jasa, penguasaan iptek dan berkembangnya inovasi, terjaganya kesinambungan fiskal, meningkatnya daya saing produk ekspor non-migas terutama produk manufaktur dan jasa, meningkatnya daya saing dan peranan usaha mikro, kecil dan menengah (UMKM) dan koperasi, serta meningkatnya ketersediaan lapangan kerja dan kesempatan kerja yang berkualitas.

Jika melihat perkembangan ekonomi Kalimantan Timur sampai dengan triwulan III 2017, terjadi pertumbuhan 3,6\% (year on year (yoy)) dimana angka tersebut menunjukkan peningkatan pertumbuhan ekonomi dibandingkan pada tahun 2016 yang berada pada angka $-0,4 \%$ (yoy). Namun angka pertumbuhan ekonomi tersebut masih berada di bawah pertumbuhan ekonomi nasional yang berada pada angka 5,1\% (yoy) pada triwulan III 2017 (Kantor Perwakilan Bank Indonesia Provinsi Kalimantan Timur, 2017). Hal tersebut secara makro masih dipengaruhi oleh dominannya sektor pertambangan dan penggalian perekonomian Provinsi Kalimantan Timur. Pada tahun 2016 tercatat sektor pertambangan dan penggalian menguasai 43,34\% dari keseluruhan PDRB Provinsi Kalimantan Timur (BPS Kaltim, 2017). Sementara itu, sektor industri pengolahan yang merupakan salah satu indikator kinerja dari percepatan transformasi ekonomi masih berada di peringkat ke dua dengan pangsa 20,51\% dari PDRB Provinsi Kalimantan Timur Tahun 2016.

Berdasarkan kecenderungan perkembangan ekonomi di Kalimantan Timur tersebut, peningkatan perekonomian harus dilakukan melalui transformasi ekonomi yaitu dengan mengurangi ketergantungan pada sektor pertambangan dan penggalian. Pertumbuhan ekonomi yang baik pada suatu daerah akan memiliki pengaruh ke berbagai aspek, salah satunya dalam menciptakan peluang kerja. Hal tersebut disebabkan karena pertumbuhan ekonomi akan berkaitan dengan peningkatan produksi barang dan jasa, yang antara lain diukur dengan besaran yang disebut Produk Domestik Regional Bruto (PDRB). Dengan meningkatnya produksi barang dan jasa maka akan menghasilkan kekayaan daerah karena dapat menciptakan peluang kerja di daerah (Boediono, 1999 dalam Sudarmono, 2006)

Melihat gambaran kondisi perkonomian di Kalimantan Timur tersebut, tentunya stakeholders di Kalimantan Timur, khususnya pemerintah, harus segera mengambil langkah-langkah konkrit dan strategis dalam rangka mendukung percepatan transformasi ekonomi di Kalimantan Timur. Untuk itu, perlu dilakukan kajian untuk mengetahui apakah telah terjadi perubahan struktur (transformasi) ekonomi di Provinsi Kalimantan Timur sebagaimana yang dicanangkan oleh Pemerintah Provinsi Kalimantan Timur sebagai salah satu prioritas pembangunan dalam RPJMD Provinsi Kalimantan Timur Tahun 2013-2018.

\section{B. METODE PENELITIAN}

Penelitian ini dilakukan dengan menggunakan metode kuantitatif melalu studi deskriptif. Studi deskriptif merupakan metode numerik dan grafis untuk mengenali pola sejumlah data, merangkum informasi yang terdapat dalam data tersebut dan menyajikan informasi tersebut dalam bentuk yang diinginkan (Kuncoro, 2011) Jenis data yang digunakan adalah data sekunder yang berasal dari

Badan Pusat Statistik Indonesia yang meliputi PDRB Provinsi Kalimantan Timur dan PDB Indonesia menurut lapangan usaha berdasarkan harga konstan dari tahun 2010 sampai dengan 2016. Adapun teknik analisis data dilakukan dengan menggabungkan hasil analisis Location Quotient (LQ) dan analisis shift share. 


\section{Location Quotient (LQ)}

LQ digunakan untuk menentukan subsektor unggulan atau ekonomi basis suatu perekonomian wilayah. Subsektor unggulan yang berkembang dengan baik tentunya mempunyai pengaruh yang signifikan terhadap pertumbuhan ekonomi daerah yang pada akhirnya dapat meningkatkan pendapatan daerah secara optimal. Perhitungan indeks LQ mengacu pada formula yang dikemukakan oleh Blakely (2002) dalam Sudarmono (2006) sebagai berikut:

$$
L Q=\frac{y_{i} / y}{Y_{i} / Y}
$$

Keterangan :

$$
\begin{array}{ll}
L Q & =\text { indeks location quotient } \\
y_{i} & =\text { nilai PDRB sektor } i \text { di Provinsi Kalimantan Timur } \\
y & =\text { nilai PDRB total Provinsi Kalimantan Timur } \\
Y_{i} & =\text { nilai PDB sektor } i \text { Indonesia } \\
Y & =\text { nilai PDB total Indonesia }
\end{array}
$$

Kriteria yang digunakan adalah apabila $L Q>1$, maka sektor tersebut dikategorikan sebagai sektor basis, yang artinya bahwa sektor tersebut potensial untuk dikembangkan karena mampu menggerakkan perekonomian daerah. Bila $\mathrm{LQ}<1$, maka sektor tersebut dikategorikan sebagai sektor non basis, yang artinya sektor tersebut hanya mampu memenuhi kebutuhan dalam daerah sehingga kurang potensial untuk dikembangkan sebagai penggerak perekonomian daerah.

\section{Shift Share}

Analisis shift share memberikan informasi terkait dengan kinerja perekonomian kedalam 3 (tiga) informasi dasar yang berhubungan satu sama lainnya, yaitu pertumbuhan ekonomi, pergeseran proporsional dan pergeseran diferensial. Pertumbuhan ekonomi (economic growth) daerah yang diukur dengan menganalisis perubahan perekonomian sektoral di daerah yang dibandingkan dengan perubahan pada sektor yang sama pada perekonomian secara nasional. Pergeseran proporsional (proportional shift), yang mengukur pertumbuhan relative produksi suatu sektor di daerah dibandingkan dengan perekonomian yang lebih besar yang dijadikan acuan (nasional). Pergeseran differensial (differensial shift) dapat mengukur daya saing suatu sektor di suatu wilayah dibandingkan dengan pertumbuhan sektor yang sama di wilayah lain.

Persamaan modelshift share yang dikemukakan (Budiharsono,2005) dalam Mahrita dkk (2016) adalah sebagai berikut:

$$
\Delta Y_{i j}=P_{i}+P S_{i}+D S_{i}
$$

Atau secara rinci dapat diuraikan sebagai berikut:

$$
\Delta Y_{i j}=y_{i o}\left(R_{a}-1\right)+y_{i o}\left(R_{i}-R_{a}\right)+y_{i o}\left(r_{i}-R_{i}\right)
$$

Dimana:

$$
\begin{aligned}
& R_{a}=Y_{t} / Y_{o} \\
& R_{i}=Y_{i t} / Y_{i o} \\
& r_{i}=y_{i t} / y_{i o}
\end{aligned}
$$


Keterangan:

$$
\begin{array}{ll}
\Delta Y_{i j} & =\text { perubahan PDRB sektor i di Provinsi Kalimantan Timur } \\
y_{i o} & =\text { PDRB sektor i Provinsi Kalimantan Timur di tahun awal } \\
y_{i t} & =\text { PDRB sektor i Provinsi Kalimantan Timur di tahun akhir } \\
Y_{i o} & =\text { PDB sektor i nasional di tahun awal } \\
Y_{i t} & =\text { PDB sektor i nasional di tahun akhir } \\
Y_{o} & =\text { jumlah total PDB nasional di tahun awal } \\
Y_{t} & =\text { jumlah total PDB nasional di tahun akhir } \\
\left(R_{a}-1\right) & =\text { Perubahan PDRB yang disebabkan oleh pertumbuhan ekonomi nasional (P) } \\
\left(R_{i}-R_{a}\right) & =\text { Perubahan PDRB yang disebabkan oleh komponen proportional shift (PS) } \\
\left(r_{i}-R_{i}\right) & =\text { Perubahan PDRB yang disebabkan oleh komponen differential shift (DS) }
\end{array}
$$

Nilai PS $>0$ menunjukkan bahwa sektor i di Provinsi Kalimantan Timur pertumbuhannya cepat sedangkan nilai PS $<0$ menunjukkan bahwa sektor i di Provinsi Kalimantan Timur pertumbuhannya lambat. Sementara itu, nilai DS $>0$ menunjukkan bahwa sektor i di Provinsi Kalimantan Timur memiliki daya saing yang kuat sedangkan nilai DS $<0$ menunjukkan bahwa sektor i di Provinsi Kalimantan Timur memiliki daya saing yang lemah.

\section{KERANGKA TEORI}

\section{Produk Domestik Regional Bruto (PDRB)}

Salah satu indikator yang digunakan dalam mengukur pendapatan suatu negara atau daerah adalah dengan menghitung besarnya nilai output dihasilkan suatu negara atau daerah dalam perekonomiannya. Istilah yang digunakan untuk mengukur pendapatan tersebut adalah Produk Domestik Bruto (PDB) atau Produk Domestik Regional Bruto (PDRB). PDB atau PDRB merupakan nilai barang dan jasa akhir berdasarkan harga pasar yang diproduksi oleh sebuah perekonomian pada suatu periode tertentu dengan mengggunakan faktor-faktor produksi yang berada di dalam perekonomian tersebut (Rahadja dan Manurung, 2008).

Perhitungan PDB atau PDRB merupakan hasil perkalian antara harga barang yang diproduksi dengan jumlah barang yang dihasilkan. Hal tersebut menyebabkan perhitungan PDB atau PDRB terbagi menjadi dua yaitu atas dasar harga berlaku dan harga konstan. Harga berlaku merupakan harga produk yang berlaku pada tahun perhitungan sedangkan harga konstan diperoleh dengan menentukan tahun dasar (based year) yang merupakan tahun di mana perekonomian berada dalam kondisi baik/stabil. Sehingga untuk mengukur pertumbuhan ekonomi yang digunakan adalah harga konstan karena perubahan PDB atau PDRB akan menunjukkan perubahan kuantitas barang atau jasa yang dihasilkan pada periode perhitungan (Rahadja dan Manurung, 2008).

\section{Teori Perubahan Struktural}

Teori Perubahan Strukturalmenitikberatkan pada pembahasan mengenai mekanisme transformasi ekonomi yang dialami negara sedang berkembang yang semula lebih subsisten ke struktur perekonomian yang lebih modern dan didominasi oleh sektor industri dan jasa (Todaro, 2004 dalam Guntara, 2017). Proses perubahan struktur ekonomi terkadang juga didefinisikan sebagai proses industrialisasi. Terjadinyaindustrialisasidapat dilihat melalui kenaikan kontribusi sektor industri manufaktur dalam permintaan konsumen, total PRDB, ekspor dan kesempatan kerja. 
Transformasi ekonomi sendiri diartikan sebagai proses perubahan struktur ekonomi, ditandai dengan pergeseran dari satu sektor ekonomi kepada sektor ekonomi lainnya yang dapat mempengaruhi PDRB pada suatu negara atau suatu daerah (Abdiyanto, 2003). Selain itu, transformasi ekonomi juga merupakan salah satu indikator terjadinya pembangunan perekonomian wilayah. Jika terjadi proses transformasi ekonomi maka dapat dinyatakan bahwa telah terjadi pembangunan ekonomi dan perlu pengembangan lebih lanjut, akantetapi jika tidak terjadi proses transformasi maka pemerintah daerah perlu mengadakan perbaikan dalam penyusunan perencanaan wilayahnya, sehingga kebijakan pembangunan yang disusun menjadi lebih terarah agar tujuan pembangunan dapat tercapai (Tambunan, 2001).

RPJMD Provinsi Kalimantan Timur Tahun 2013-2018 menyatakan bahwa transformasi ekonomi di Provinsi Kalimantan Timur dilakukan dengan memperbaiki struktur ekonomi yang awalnya berbasis SDA tak terbarukan menjadi ekonomi berbasis SDA terbarukan dalam rangka menjamin keberlanjutan pembangunan ekonomi Provinsi KalimantanTimur di masa mendatang.Hal tersebut tentunya dilatarbelakangi dengan ketergantungan perekonomian Kalimantan Timur terhadap sektor pertambangan dan penggalian terhadap SDA tak terbarukan yang suatu saat pasti akan habis.

Peluang industri pengolahan sebagai pengganti dominasi sektor pertambangan dan penggalian di Kalimantan Timur cukup besar dikarenakan kedua sektor tersebut merupakan merupakan sektor yang menjadi basis perekonomian di Kalimantan Timur pada periode 2003 - 2013 (Mahrita dkk, 2016). Hal tersebut juga terjadi sampai dengan tahun 2016 dimana gabungan dari kedua sektor tersebut menguasi lebih dari 70\% PDRB Provinsi Kalimantan Timur. Sehingga industri pengolahan merupakan sektor yang dapat dijadikan pengganti sektor pertambangan dan penggalian dibandingkan sektor non basis seperti pertanian, sektor listrik gas dan air bersih, konstruksi bangungan, perdagangan, hotel dan resetoran, keuangan dan jasa-jasa.

\section{Konsep Location Quotient (LQ)}

Menurut Mahrita dkk (2016), location quotient disingkat LQ adalah suatu metode untuk mengukur spesialisasi relatif dari suatu wilayah/daerah dalam industri-industri tertentu. Metode LQ dapat digunakan untuk mengetahui kapasitas ekspor yang dimiliki oleh daerah atau dengan kata lain mengetahui spesialisasi yang dimililki oleh daerah dibandingkan dengan daerah yang tingkatannya lebih tinggi atau sektor lain yang memiliki kategori yang sama.

Dasar pemikiran konsep LQ adalah teori basis ekonomi. Teori basis ekonomi ini menyatakan bahwa faktor penentu utama pertumbuhan ekonomi suatu daerah adalah berhubungan langsung dengan permintaan akan suatu barang dan jasa dari luar daerah. Proses produksi di sektor atau industri di suatu daerah yang menggunakan sumber daya produksi (SDP) lokal, termasuk tenaga kerja dan bahan baku dimana outputnya diekspor akan menghasilkan pertumbuhan ekonomi, peningkatan pendapatan perkapita dan penciptaan peluang kerja di daerah tersebut (Tambunan, 2001).

\section{Shift Share}

Menurut Sari (2013), shift share adalah salah satu teknik kuantitatif yang biasa digunakan untuk menganalisis perubahan struktur ekonomi daerah relatif terhadap struktur ekonomi wilayah yang lebih tinggi sebagai pembanding atau referensi. Sementara itu, menurut Goschim (2014) dalam Abidin (2015), pendekatan shift share ini diperkenalkan pertama kali oleh Dunn tahun 1960 untuk menjelaskan perubahan ekonomi yang dipengaruhi oleh sektor secara nasional, regional dan lokal. Analisis shift share ini menggunakan 3 informasi dasar yang berhubungan satu sama lain yaitu 
a. Pertama komponen pertumbuhan provinsi (national/provincial growth component atau share regional). Komponen ini adalah untuk melihat struktur atau posisi relatif suatu daerah dalam kaitannya dengan pertumbuhan ekonomi secara menyeluruh di wilayah yang acuan atau wilayah yang lebih luas. Share regional menggambarkan perubahan output suatu wilayah yang disebabkan oleh perubahan secara umum, perubahan kebijakan ekonomi secara nasional atau provinsi.

b. Kedua pertumbuhan sektoral (industrial mix component atau proportionally shift), merupakan komponen untuk mengukur cepat atau lambannya tingkat pertumbuhan produksi suatu wilayah dilihat dari pertumbuhan produksi nasional karena tingginya konsentrasi industri (sektor) regional. Proportionnaly Shift (PS) dipengaruhi oleh perubahan permintaan akhir, ketersediaan bahan baku, dan kebijakan sektoral. Selain itu komponen pertumbuhan proporsional tumbuh karena perbedaan sektor dalam permintaan produk akhir, perbedaan ketersediaan bahan mentah, perbedaan kebijakan industri dan perbedaan struktur, dan keragaman pasar.

c. Ketiga pertumbuhan daya saing wilayah (competitive effect component atau different shift). Different shift dapat mengukur daya saing suatu sektor di suatu wilayah dibandingkan dengan pertumbuhan sektor yang sama di wilayah lain. Different shift terjadi karena peningkatan atau penurunan output di suatu wilayah yang disebabkan oleh keunggulan komparatif, akses ke pasar input dan output, maupun infrastruktur ekonomi.

\section{HASIL DAN PEMBAHASAN}

\section{PDRB Sektor Industri Pengolahan dan Pertambangan dan Penggalian}

Percepatan transformasi ekonomi di Kalimantan Timur ditetapkan menjadi salah satu dari dua belas prioritas pembangunan di dalam RPJMD Provinsi Kalimantan Timur 2013-2018. Arah transformasi ekonomi yang dilakukan oleh Pemerintah Provinsi Kalimantan Timur adalah dengan mengurangi ketergantungan perekonomian Kalimantan Timur terhadap sektor pertambangan dan penggalian yang digantikan dengan sektor industri pengolahan. Namun jika melihat perbandingan nilai PDRB industri pengolahan tahun 2010-2016 seperti yang ditampilkan pada Tabel 1 menunjukkan bahwa nilai PDRB sektor industri pengolahan masih berada di bawah 50\% dibandingkan nilai PDRB sektor pertambangan dan penggalian.

Tabel 1 .

Perbandingan PDRB Sektor Pertambangan dan Penggalian dengan Sektor Indusri Pengolahan Provinsi Kalimantan Timur atas dasar harga konstan 2010

(dalam juta rupiah)

\begin{tabular}{cccc}
\hline Tahun & $\begin{array}{c}\text { PDRB Pertambangan dan } \\
\text { Penggalian }\end{array}$ & $\begin{array}{c}\text { PDRB Industri } \\
\text { Pengolahan }\end{array}$ & Perbandingan \\
\hline 2010 & 201.663 .286 & 98.094 .587 & $1: 0,49$ \\
2011 & 222.952 .267 & 94.724 .892 & $1: 0,42$ \\
2012 & 228.444 .298 & 87.788 .850 & $1: 0,38$ \\
2013 & 232.661 .007 & 86.201 .392 & $1: 0,37$ \\
2014 & 231.725 .331 & 86.590 .089 & $1: 0,37$ \\
2015 & 220.405 .121 & 88.889 .323 & $1: 0,40$ \\
2016 & 212.646 .364 & 93.740 .627 & $1: 0,44$ \\
\hline
\end{tabular}

Sumber: BPS. Prov. Kaltim (2015-2017) 
Sektor pertambangan dan penggalian dan sektor industri pengolahan merupakan kontributor terbesar pada distribusi PDRB Kalimantan Timur tahun 2010-2016. Hal tersebut terlihat pada Gambar 1 yangmenunjukkan bahwa sektor pertambangan dan penggalian dan industri pengolahan menguasai pangsa PDRB Provinsi Kalimantan Timur sekitar 70\% pada tahun 2010-2016.

Jika melihat laju pertumbuhan PDRB, pada Gambar 2 terlihat bahwa pertumbuhan sektor pertambangan dan penggalian terus mengalami penurunan dalam kurun tahun 2010-2016. Hal tersebut berbanding terbalik dengan sektor industri pengolahan yang terus mengalami peningkatan dari tahun 2010 sampai dengan 2016. Sektor industri pengolahan sempat mengalami penurunan drastis pada tahun 2012 yaitu sebesar $-7,32 \%$ namun perlahan meningkat pada tahun-tahun berikutnya.

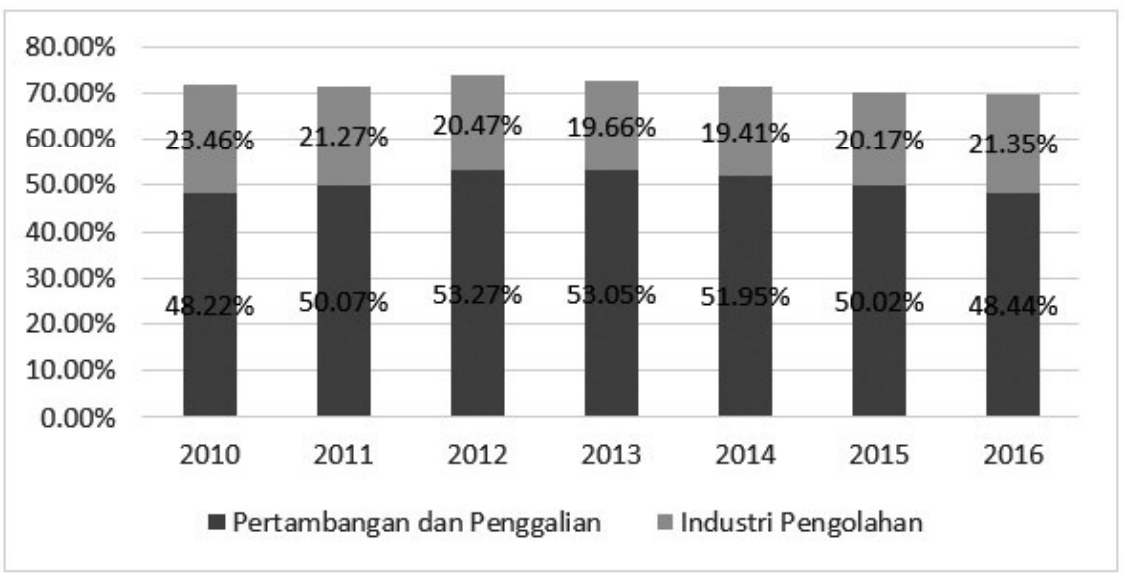

Sumber: BPS. Prov. Kaltim (2015-2017)

Gambar 1.

Distribusi PDRB sektor pertambangan dan penggalian dan sektor industri pengolahan 2010-2016

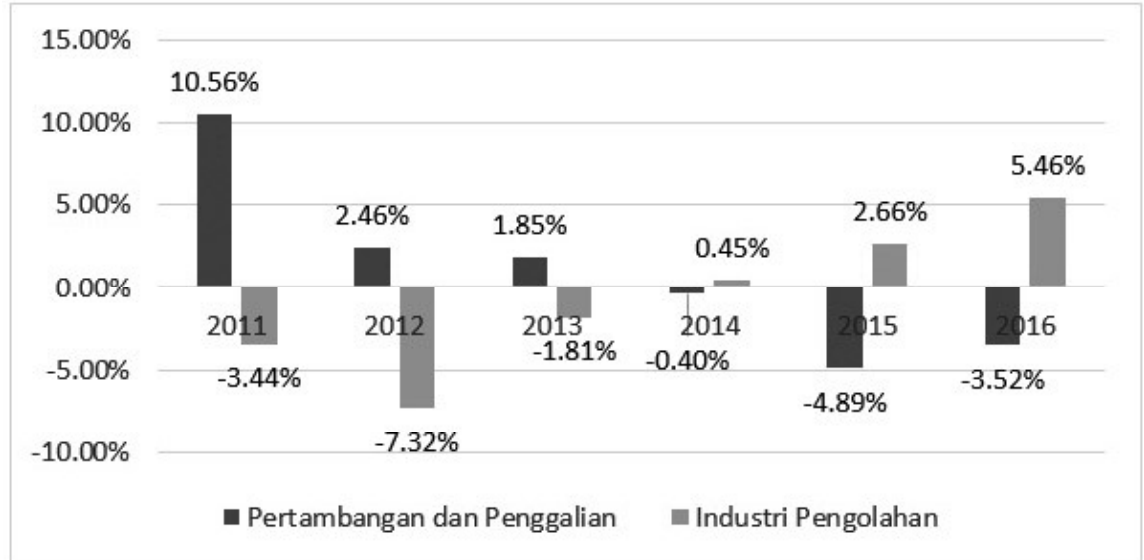

Sumber: BPS. Prov. Kaltim (2015-2017)

Gambar 2.

Laju pertumbuhan PDRB sektor pertambangan dan penggalian dan sektor industri pengolahan 2010-2016

\section{Location Quotient (LQ) Provinsi Kalimantan Timur}

Dari perhitungan indeks LQ dengan menggunakan persamaan (1) sebagaimana ditampilkan pada Tabel 2, terlihat bahwa dari tahun 2010 sampai dengan 2016, sektor pertambangan dan 
penggalian merupakan sektor basis dalam perekonomian Kalimantan Timur. Sedangkan sektor industri pengolahan menjadi sektor basis pada tahun 2010 namun kemudian pada tahun 2011 sampai dengan 2016 menjadi sektor non basis walaupun nilai indeks LQ sektor industri pengolahan merupakan yang tertinggi di luar sektor pertambangan dan penggalian. Hal tersebut menunjukkan bahwa sektor pertambangan dan penggalian dan sektor industri pengolahan merupakan sektor yang dominan di Provinsi Kalimantan Timur dan mampu memenuhi kebutuhan di dalam dan di luar wilayah Provinsi Kalimantan Timur.

Tabel 2.

Indeks Location Quotient Provinsi Kalimantan Timur Berdasarkan Lapangan Usaha Tahun 2010-2016

\begin{tabular}{lccccccc}
\hline \multicolumn{1}{c}{ Lapangan Usaha } & \multicolumn{7}{c}{ Tahun } \\
& 2010 & 2011 & 2012 & 2013 & 2014 & 2015 & 2016 \\
\hline $\begin{array}{l}\text { Pertanian, Kehutanan dan } \\
\text { Perikanan }\end{array}$ & 0,46 & 0,47 & 0,48 & 0,43 & 0,45 & 0,48 & 0,49 \\
Pertambangan dan Penggalian & 4,49 & 4,78 & 5,03 & 5,33 & 5,46 & 5,67 & 5,68 \\
Industri Pengolahan & 1,04 & 0,95 & 0,87 & 0,88 & 0,87 & 0,91 & 0,96 \\
$\begin{array}{l}\text { Pengadaan Listrik dan Gas } \\
\text { Pengadaan Air, Pengelolaan }\end{array}$ & 0,03 & 0,03 & 0,03 & 0,03 & 0,03 & 0,04 & 0,05 \\
Sampah, Limbah dan Daur Ulang & 0,49 & 0,50 & 0,49 & 0,49 & 0,50 & 0,51 & 0,55 \\
Konstruksi & & & & & & & \\
Perdagangan Besar dan Eceran; & 0,74 & 0,72 & 0,72 & 0,68 & 0,70 & 0,69 & 0,66 \\
Reparasi Mobil dan Sepeda Motor & 0,36 & 0,36 & 0,36 & 0,33 & 0,34 & 0,35 & 0,36 \\
Transportasi dan Pergudangan & 0,69 & 0,70 & 0,71 & 0,65 & 0,67 & 0,68 & 0,68 \\
Penyediaan Akomodasi dan & 0,22 & 0,22 & 0,23 & 0,21 & 0,22 & 0,23 & 0,24 \\
Makan Minum & & & & & & & \\
Informasi dan Komunikasi & 0,29 & 0,29 & 0,29 & 0,27 & 0,27 & 0,28 & 0,29 \\
Jasa Keuangan dan Asuransi & 0,33 & 0,33 & 0,34 & 0,37 & 0,37 & 0,37 & 0,36 \\
Real Estat & 0,25 & 0,25 & 0,25 & 0,26 & 0,28 & 0,29 & 0,29 \\
Jasa Perusahaan & 0,12 & 0,12 & 0,12 & 0,12 & 0,12 & 0,11 & 0,11 \\
Administrasi Pemerintahan, & 0,49 & 0,50 & 0,51 & 0,45 & 0,49 & 0,52 & 0,51 \\
Pertahanan dan Jamsos Wajib & & & & & & & \\
Jasa Pendidikan & 0,25 & 0,29 & 0,32 & 0,33 & 0,36 & 0,39 & 0,42 \\
Jasa Kesehatan dan Kegiatan & 0,40 & 0,41 & 0,42 & 0,38 & 0,39 & 0,43 & 0,47 \\
Sosial & & & & & & & \\
Jasa lainnya & 0,27 & 0,27 & 0,26 & 0,26 & 0,26 & 0,28 & 0,29 \\
\hline
\end{tabular}

Sumber : Diolah dari data BPS Tahun 2015-2017

Nilai indeks LQ pada Tabel 2 menunjukkan bahwa selain sektor pertambangan dan penggalian dan industri pengolahan keseluruhannya merupakan sektor non basis karena indeks LQ bernilai kurang dari 1. Hal ini menunjukkan bahwa sektor-sektor tersebut tidak dapat memenuhi permintaan komoditi di luar wilayah Provinsi Kalimantan Timur dan hanya mampu memenuhi kebutuhan dalam daerah Provinsi Kalimantan Timur. Dengan demikian hanya sektor industri pengolahan yang memiliki kecenderungan untuk menjadi sektor basis bersama dengan sektor pertambangan dan penggalian karena mengalami peningkatan nilai indeks dari tahun 2014 sampai dengan 2016 yang hampir mendekati nilai 1 . 


\section{Shift Share Provinsi Kalimantan Timur}

Hasil analisis shift share yang tersaji pada Tabel 3 menunjukkan bahwa peningkatan PDRB Provinsi Kalimantan Timur sebesar Rp. 150.955.790,00 juta sepanjang tahun 2010-2016 dipengaruhi oleh pertumbuhan PDB Indonesia. Sektor di Provinsi Kalimantan Timur yang paling terpengaruh oleh perubahan PDB di tingkat nasional adalah sektor pertambangan dan penggalian karena memiliki nilai P yang tertinggi di antara sektor-sektor lainnya yaitu Rp. 72.791.479,00 juta. Sementara sektor berikutnya yang paling terpengaruh oleh perubahan PDB nasional adalah sektor industri pengolahan dengan nilai P sebesar Rp. 35.407.784,00 juta. Hal tersebut mengindikasikan bahwa jika terjadi perubahan PDB di tingkat nasional, maka sektor pertambangan dan penggalian dan sektor industri pengolahan akan menjadi sektor yang paling terpengaruh terhadap kemampuannya dalam pembentukan PDRB.

Tabel 3.

Analisis Shift Share Perekonomian Provinsi Kalimantan Timur Terhadap Nasional Berdasarkan Lapangan Usaha Tahun 2010-2016 (juta rupiah)

\begin{tabular}{|c|c|c|c|c|}
\hline Lapangan Usaha & $\mathbf{P}$ & PS & DS & $\Delta \mathrm{Y}$ \\
\hline $\begin{array}{l}\text { Pertanian, Kehutanan, } \\
\text { Perikanan }\end{array}$ & $9.891 .313,00$ & $-2.623 .871,00$ & $-6.031 .538,00$ & $1.235 .904,00$ \\
\hline $\begin{array}{l}\text { Pertambangan dan } \\
\text { Penggalian }\end{array}$ & $72.791 .479,00$ & $-56.684 .613,00$ & $-5.123 .788,00$ & $10.983 .078,00$ \\
\hline Industri Pengolahan & $35.407 .784,00$ & $-2.674 .527,00$ & $-37.087 .217,00$ & $-4.353 .960,00$ \\
\hline $\begin{array}{l}\text { Pengadaan Listrik dan } \\
\text { Gas }\end{array}$ & $41.554,00$ & $2.021,00$ & $64.700,00$ & $108.275,00$ \\
\hline $\begin{array}{l}\text { Pengadaan Air, } \\
\text { Pengelolaan Sampah, } \\
\text { Limbah dan Daur } \\
\text { Ulang }\end{array}$ & $64.653,00$ & $-9.952,00$ & $-32.093,00$ & $22.608,00$ \\
\hline Konstruksi & $10.484 .800,00$ & $3.330 .159,00$ & $-13.212 .876,00$ & $602.083,00$ \\
\hline $\begin{array}{l}\text { Perdagangan Besar dan } \\
\text { Eceran; Reparasi Mobil } \\
\text { dan Sepeda Motor }\end{array}$ & $7.410 .709,00$ & $-48.760,00$ & $-5.861 .678,00$ & $1.500 .271,00$ \\
\hline $\begin{array}{l}\text { Transportasi dan } \\
\text { Pergudangan }\end{array}$ & $3.818 .890,00$ & $1.803 .143,00$ & $-3.817 .127,00$ & $1.804 .906,00$ \\
\hline $\begin{array}{l}\text { Penyediaan Akomodasi } \\
\text { dan Makan Minum }\end{array}$ & $998.036,00$ & $132.888,00$ & $-608.592,00$ & $522.333,00$ \\
\hline $\begin{array}{l}\text { Informasi dan } \\
\text { Komunikasi }\end{array}$ & $1.666 .509,00$ & $1.996 .083,00$ & $-1.795 .721,00$ & $1.866 .871,00$ \\
\hline $\begin{array}{l}\text { Jasa Keuangan dan } \\
\text { Asuransi }\end{array}$ & $1.779 .620,00$ & $1.068 .929,00$ & $-1.206 .563,00$ & $1.641 .986,00$ \\
\hline Real Estat & $1.139 .474,00$ & $138.769,00$ & $-533.179,00$ & $745.064,00$ \\
\hline Jasa Perusahaan & $258.999,00$ & $177.208,00$ & $-329.105,00$ & $107.102,00$ \\
\hline $\begin{array}{l}\text { Administrasi } \\
\text { Pemerintahan, }\end{array}$ & $2.858 .178,00$ & $-1.019 .013,00$ & $-1.859 .590,00$ & $-20.425,00$ \\
\hline \multicolumn{5}{|l|}{$\begin{array}{l}\text { Pertahanan dan Jamsos } \\
\text { Wajib }\end{array}$} \\
\hline Jasa Pendidikan & $1.134 .093,00$ & $304.966,00$ & $1.363 .204,00$ & $2.802 .263,00$ \\
\hline $\begin{array}{l}\text { Jasa Kesehatan dan } \\
\text { Kegiatan Sosial }\end{array}$ & $593.046,00$ & $294.501,00$ & $-204.718,00$ & $682.828,00$ \\
\hline Jasa lainnya & $616.654,00$ & $315.422,00$ & $-417.813,00$ & $514.262,00$ \\
\hline Total & $150.955 .790,00$ & $-53.496 .647,00$ & $-76.693 .693,00$ & $20.765 .449,00$ \\
\hline
\end{tabular}

Sumber : Diolah dari data BPS Tahun 2015-2017 
Komponen pertumbuhan ekonomi berikutnya adalah proportional shift (PS). Nilai PS untuk sektor industri pengolahan dan pertambangan dan penggalian menunjukkan nilai negatif yang berarti bahwa pertumbuhan kedua sektor tersebut lamban. Sektor pertambangan dan penggalian merupakan sektor yang pertumbuhan ekonomi nya paling lamban di Provinsi Kalimantan Timur pada tahun 2010-2016 karena memiliki nilai PS terkecil yaitu Rp. -56.684.613,00 juta. Sektor industri pengolahan juga merupakan sektor yang pertumbuhan ekonomi nya lamban karena nilai PS sektor industri pengolahan menunjukkan angka Rp. -2.674.527,00 juta.

Selanjutnya yaitu komponen differential shift (DS) untuk sektor industri pengolahan merupakan nilai terkecil dibanding sektor-sektor lainnya dengan nilai Rp. - 37.087.217,00 juta sedangkan sektor pertambangan dan penggalian memiliki nilai DS Rp. -5.123.788,00 juta. Hal tersebut menunjukkan bahwa sektor industri pengolahan yang diunggulkan Pemerintah Provinsi Kalimantan Timur dalam mempercepat transformasi ekonomi memiliki daya saing yang paling lemah diantara sektor-sektor lainnya pada periode 2010-2016.

Penjumlahan ketiga komponen di atas menghasilkan nilai perubahan bersih ( ekonomi di Kalimantan Timur pada tahun 2010-2016. Tabel 3 menunjukkan bahwa sektor pertambangan dan penggalian masih merupakan sektor yang menyumbangkan pertumbuhan bersih PDRB terbesar di Provinsi Kalimantan Timur dengan nilai Rp. 10.983.078,00 juta. Sebaliknya sektor industri pengolahan justru merupakan sektor yang memiliki nilai pertumbuhan bersih PDRB paling rendah yaitu sebesar Rp. $-4.353 .960,00$ juta.

Secara keseluruhan dari hasil analisis shift share, pertumbuhan sektor industri pengolahan yang merupakan salah satu indikator dalam keberhasilan transformasi ekonomi ternyata rentan terhadap perubahan PDB secara nasional. Selain itu, sektor industri pengolahan di Provinsi Kalimantan Timurmemiliki pertumbuhan yang lamban serta memiliki daya saing yang lemah, yang mengindikasikan bahwa kebijakan transformasi ekonomi di Provinsi Kalimantan Timur belum terlaksana secara efektif dan sektor pertambangan dan penggalian masih merupakan sektor yang menopang perekonomian di Provinsi Kalimantan Timur sepanjang tahun 2010-2016. Hal ini sesuai dengan pendapat Kuncoro dan Idris (2010) yang menyebutkan bahwa Kalimantan Timur merupakan contoh daerah yang mengalami gejala growth without development yang disebabkan karena tidak terjadinya transformasi struktural dalam perekonomian Kalimantan Timur. Tidak terjadinya transformasi struktural dalam perekonomian Kalimantan Timur karena belum menerapkan strategi industrialisasi dalam perekonomiannya, bahkan mengalami gejala deindustrialisasi. Melimpahnya ketersediaan minyak dan gas serta dominannya sektor pertambangan dan penggalian merupakan sebab tidak terjadinya industrialisasi.

\section{Potensi Pengembangan Sektor Industri Pengolahan di Kalimantan Timur}

Meskipun Pemerintah Provinsi Kalimantan Timur mencanangkan transformasi ekonomi dengan mengembangkan sektor industri berbasis SDA terbarukan melalui hilirisasi industri, peran sektor pertambangan dan penggalian tidak dapat serta merta untuk ditinggalkan mengingat sektor tersebut lah yang menggerakkan ekonomi di Kalimantan Timur dalam kurun waktu 10 tahun terakhir. Pemerintah Provinsi Kalimantan Timur perlu untukmulai membatasi dan mengevaluasi Ijin Usaha Pertambangan (IUP) yang ada saat ini sembari membangun sektor sekunder dan tersier agar lebih produktif sehingga mampu menjadi penggerak perekonomian yang baru dalam meningkatkan kesejahteraan masyarakat di Kalimantan Timur (Zaini, 2017).

Namun jika melihat apa yang terjadi pada perekonomian Kalimantan Timur di masa lalu, sektor industri pengolahan juga pernah mengalami masa kejayaan khususnya pada sektor migas. 
Dengan memperhitungkan sektor migas pada PDRB Provinsi Kalimantan Timur, posisi sektor industri pengolahan merupakan kontributor terbesar pada tahun 1993 namun digantikan oleh sektor pertambangan dan penggalian pada tahun 2007 (Kuncoro dan Idris, 2010). Dengan demikian, jika melihat kecenderungan tersebut maka Pemerintah Provinsi Kalimantan Timur harus menggerakkan sektor industri pengolahan non-migas yang potensial jika ingin melakukan perubahan struktur ekonomi secara berkelanjutan yang mengandalkan sektor industri pengolahan.

Berdasarkan hasil pemetaan industri unggulan daerah berdasarkan tingkat daya saing dan aglomerasi, industri yang potensial untuk dikembangkan di Kalimantan Timur adalah pengolahan kelapa sawit (Asmara dan Zuliastri, 2014). Aglomerasi industri diartikan sebagai pengelompokkan industri inti yang saling berhubungan dengan industri pendukung, industri terkait, jasa penunjang dan infrastruktur ekonomi. Pengembangan industri pengolahan kelapa sawit di Kalimantan Timur telah sejalan dengan program Pemerintah Provinsi Kalimantan Timur yaitu pengembangan Kawasan Industri Oleochemical Maloy di Kabupaten Kutai Timur (Bappeda Prov. Kaltim, 2016). Dalam perkembangannya, kawasan industri tersebut ditetapkan menjadi Kawasan Ekonomi Khusus (KEK) berdasarkan Peraturan Pemerintah Nomor 85 Tahun 2014 tentang KEK Maloy Batuta Trans Kalimantan(MBTK). Hal tersebut dilakukan dalam rangka mewujudkan kawasab industri tersebut sebagai pusat pengolahan oleochemical yang berskala internasional mencakup industri hulu sampai ke hilirnya (Fitrian, 2017).

\section{E. PENUTUP}

Pemerintah Provinsi Kalimantan Timur melalui RPJMD Tahun 2013-2018 mencanangkan program transformasi ekonomi secara bertahap dengan meningkatkan nilai tambah dan produktifitas pada SDA yang terbarukan. Hal tersebut juga dimaksudkan untuk mengurangi ketergantungan perekonomian Kalimantan Timur terhadap sektor pertambangan dan penggalian. Hasil perhitungan indeks LQ menunjukkan bahwa sektor pertambangan dan penggalian merupakan satu-satunya sektor basis di Provinsi Kalimantan Timur. Sedangkan sektor industri pengolahan belum menjadi sektor basis di Provinsi Kalimantan Timur pada periode 2010-2016, namun memiliki peluang ke arah tersebut karena indeks LQ industri pengolahan hampir mendekati 1 yaitu 0,96. Sementara itu, hasil analisis shift share menunjukkan bahwa sektor pertambangan dan penggalian masih merupakan sektor yang menopang perekonomian di Provinsi Kalimantan Timur sepanjang tahun 2010-2016. Sedangkan sektor industri pengolahan masih memiliki pertumbuhan ekonomi yang lamban dan berdaya saing rendah. Hal tersebut menggambarkan bahwa transformasi ekonomi di Kalimantan Timur masih belum berjalan sesuai dengan yang dicanangkan oleh Pemerintah Provinsi Kalimantan Timur.

Pemerintah Provinsi Kalimantan Timur harus mengambil langkah-langkah strategis dalam mempercepat tercapainya transformasi ekonomi di Provinsi Kalimantan Timur. Kebijakan yang dapat dilaksanakan antara lain dengan membatasi penerbitan Izin Usaha Pertambangan (IUP) serta mengevaluasi IUP yang telah diterbitkan. Selain itu, Pemerintah Provinsi Kalimantan Timur juga harus segera mengembangkan sektor industri pengolahan non-migas yang potensial di Kalimantan Timur, salah satunya industri pengolahan kelapa sawit.

Dalam rangka untuk menyempurnakan hasil penelitian ini, perlu dilakukan penelitian lanjutan yang membahas secara lebih spesifik mengenai proporsi dan potensi dari setiap golongan atau klaster industri pengolahan terhadap pertumbuhan sektor industri pengolahan di Kalimantan Timur sehingga didapatkan gambaran yang lebih komprehensif. 


\section{DAFTAR PUSTAKA}

Abdiyanto. (2003). Analisis Transformasi Ekonomi di Propinsi Sumatera Utara. Tesis Program Pascasarjana. Medan: Universitas Sumatera Utara.

Abidin, Zainal. (2015). Aplikasi Analisis Shift Share Pada Transformasi Sektor Pertanian Dalam Perekonomian Wilayah di Sulawesi Tenggara. Informatika Pertanian, 24(2), 165 - 178

Asmara, Alla dan Zuliastri, Astri Fikanti. (2014). Industri Unggulan Daerah dalam Perspektif Aglomerasi dan Daya Saing. Agrimedia, 19(2), 30-35.

Bappeda Prov. Kaltim. (2016). Kerangka Kebijakan Perubahan Rencana Pembangunan Jangka Menengah Daerah Provinsi Kalimantan Timur Tahun 2013-2018. Disampaikan pada Sosialisasi Perubahan RPJMD Tahun 2013-2018 di Samarinda pada tanggal 26 Oktober 2016.

BPS. (2015). Peraturan Kepala Badan Pusat Statistik Republik Indonesia Nomor 95 Tahun 2015. Berita Negara Republik Indonesia Tahun 2015 Nomor 1635. Jakarta.

. Produk Domestik Regional Bruto Provinsi-Provinsi di Indonesia Menurut Lapangan Usaha 2010-2014. Jakarta: Badan Pusat Statistik Indonesia.

BPS. (2017). Produk Domestik Regional Bruto Provinsi-Provinsi di Indonesia Menurut Lapangan Usaha 2012-2016. Jakarta: Badan Pusat Statistik Indonesia.

BPS Prov. Kaltim. (2017). Kalimantan Timur Dalam Angka 2017. Samarinda: Badan Pusat Statistik Provinsi Kalimantan Timur.

BPS Prov. Kaltim. (2016). Kalimantan Timur Dalam Angka 2016. Samarinda: Badan Pusat Statistik Provinsi Kalimantan Timur.

BPS Prov. Kaltim. (2015). Kalimantan Timur Dalam Angka 2015. Samarinda: Badan Pusat Statistik Provinsi Kalimantan Timur.

Fitrian, Zhikry. (2017). Pengembangan Hilirisasi Industri di Kalimantan Timur. Buletin Lembusuana, XVII (191), 9-15.

Guntara, Aditya Hardi. (2017). Transformasi Struktur Ekonomi Kabupaten IndragiriHulu Tahun 2000-2013. Jurnal Online Mahasiswa Fakultas Ekonomi Universitas Riau, 4(1), 420433.

Kantor Perwakilan Bank Indonesia Provinsi Kalimantan Timur. (2017). Kajian Ekonomi dan Keuangan Regional Provinsi Kalimantan Timur November 2017. Kantor Perwakilan Bank Indonesia Provinsi Kalimantan Timur, Samarinda.

Kuncoro, Mudrajad. (2011). Metode Kuantitatif: Teori dan Aplikasi untuk Bisnis dan Ekonomi. Yogyakarta: UPP STIM YKPN.

Kuncoro, Mudrajad dan Idris, Ahmad Nafis. (2010). Mengapa Terjadi Growth Without Development di Provinsi Kalimantan Timur. Jurnal Ekonomi Pembangunan, 11(2), 172-190.

Mahrita, Mintarti, Sri dan Fitriadi. (2016). Analisis Sektor Ekonomi Provinsi Kalimantan Timur. Jurnal Ekonomi Keuangan, 12(2), 235-249.

Pemerintah Provinsi Kalimantan Timur. (2014). Peraturan Daerah Provinsi Kalimantan Timur Nomor 7 Tahun 2014 tentang Rencana Pembangunan Jangka Menengah Pemerintah Provinsi Kalimantan Timur Tahun 2013-2018. Samarinda. 
Rahardja, Prathama dan Manurung, Mandala. (2008). Teori Ekonomi Makro : Suatu Pengantar, Edisi Keempat. Jakarta : Lembaga Penerbit Fakultas Ekonomi Universitas Indonesia.

Republik Indonesia. (2015). Peraturan Presiden Republik Indonesia Nomor 2 Tahun 2015 tentang Rencana Pembangunan Jangka Menengah Nasional 2015-2019. Lembaran Negara Republik Indonesia Tahun 2015 Nomor 3. Jakarta.

Sari, Normita Rita. (2013). Analisis Pertumbuhan Ekonomi dan Ketimpangan Pendapatan Antar Provinsi di Indonesia Tahun 2004-2010.Skripsi Program Sarjana Fakultas Ekonomi Universitas Diponegoro Semarang.

Sudarmono, Mulyanto. (2006). Analisis Transformasi Struktural Pertumbuhan Ekonomi dan Ketimpangan Antar Daerah di Wilayah Pembangunan I Jateng. Tesis Program Pascasarjana Universitas Diponegoro Semarang.

Tambunan, Tulus. (2001). Transformasi Ekonomi di Indonesia : Teori dan Penemuan Empiris. Jakarta: Salemba Empat.

Zaini, Ahmad. (2017). Pengaruh Kekayaan Sumberdaya Alam Batubara Terhadap Ketimpangan Pendapatan di Provinsi Kalimantan Timur. Jurnal Borneo Administrator, 13(2), 111-130. 